\title{
KAJIAN PENGETAHUAN MAHASISWA AKPER HERMINA MANGGALA HUSADA TENTANG COVID 19 DAN CARA PENCEGAHANNYA
}

\author{
Retno Winarti ${ }^{1}$, Suryani Hartati ${ }^{2}$ \\ ${ }^{1,2}$ Akademi Keperawatan Hermina Manggala Husada \\ E-mail: retnowinarti123@gmail.com
}

\begin{abstract}
Abstrak
Covid 19 merupakan penyakit menular yang saat ini sedang dihadapi dunia. Pengetahuan yang baik tentang covid 19 menjadi faktor yang berkontribusi dalam melakukan pencegahan penyakit covid 19. Tujuan penelitian ini untuk mengetahui pengetahuan mahasiswa tentang covid 19 dan cara pencegahannya. Penelitian crosssectional menggunakan teknik consecutive sampling dengan 110 responden mahasiswa Akper Hermina Manggala Husada. Survei dilakukan menggunakan kuesioner yang terdiri dari 20 item pertanyaan tentang penyakit covid 19 dan cara pencegahannya, Gambaran pengetahuan mahasiswa akper diukur menggunakan skala guttmen dengan cut of point 17. Hasil penelitian menunjukkan bahwa sebagian besar mahasiswa memiliki pengetahuan yang baik tentang covid 19 (56,4\%), namun masih ada 43,5\% mahasiswa yang belum memiliki pengetahuan yang baik tentang covid 19, sebagian besar mahasiswa mendapatkan informasi tentang covid 19 dari media TV dan online. Pengetahuan yang baik merupakan dasar dalam melakukan pencegahan penyakit covid 19, maka penting untuk menjadikan covid 19 sebagai bahan ajar di kelas agar seluruh mahasiswa memiliki pengetahuan yang baik tentang covid 19
\end{abstract}

Kata kunci : Covid 19, Pengetahuan Mahasiswa

\begin{abstract}
Covid 19 is an infectious disease currently being faced by the world. Good knowledge on Covid 19 contributes in preventing Covid 19. The purpose of this study is to find out the knowledge of nursing student about Covid 19 and how to prevent it. This cross-sectional study used consecutive sampling technique with 110 respondents as student of Hermina Manggala Husada Nursing Academic. The survey was conducted using a questionnaire consisting of 20 question items about Covid 19 and how to prevent it. The knowledge of nursing students was measured using a guttmen scale with a cut of point 17. Data analysis was carried out using ci square. The results showed that most of the students had good knowledge about covid 19 (56.4\%), but there were still $43.6 \%$ students who did not have good knowledge about covid 19, most students got information about covid 19 from Television and online media. Good knowledge is the basis for preventing Covid 19, so it is important to make Covid 19 a teaching material in class so that all students have good knowledge about Covid 19.
\end{abstract}

Keywords : Covid 19, Student's Knowledge

\section{Pendahuluan}

Covid 19 merupakan penyakit menular yang saat ini sedang dihadapi dunia. Penyakit covid 19 saat ini sudah menjadi permasalahan global karena selain menyebabkan kematian juga penyebarannya yang sangat cepat. Penyakit covid 19 disebut emerging 2020). infectious disease(EIDs) yang menjadi kekhawatiran khusus dalam kesehatan masyarakat, karena penyakit ini selain menyebabkan kematian penyakit ini juga membawa dampak sosial dan ekonomi yang besar dalam dunia yang telah saling berhubungan saat ini (Kemenkes RI, 
Secara global sebanyak 2.471.136 pasien terkonfirmasi positif dan 169.006 orang (6,8\%) meninggal akibat infeksi Covid 19 (Kemenkes, RI, 2020). Berdasarkan data Kementrian Kesehatan Republik Indoenesia sampai dengan tanggal 19 April 2020 sebanyak 7.775 terkonfirmasi korona Di Indonesia dan sebanyak 647 orang $(8,3 \%)$ meninggal akibat virus korona. DKI Jakarta provinsi dengan kasus covid 19 terbanyak yaitu 3517 disusul Jawa Barat dengan jumlah kasus terkonfirmasi sebanyak 784 orang, propinsi dengan jumlah kasus terbanyak ketiga adalah Jawa Timur dengan 664 kasus dan disusul Jawa Tengah dengan jumlah kasus terkonfirmasi sebanyak 538 kasus (Kemenkes RI, 2020)

Covid-19 dapat menular dari manusia ke manusia melalui kontak erat dan droplet, tidak melalui udara. Orang yang paling berisiko tertular penyakit ini adalah orang yang kontak erat dengan pasien covid-19 termasuk yang merawat pasien covid-19 (Kemenkes RI, 2020). Rekomendasi standar untuk mencegah penyebaran infeksi adalah melalui cuci tangan secara teratur, menerapkan etika batuk dan bersin, menghindari kontak secara langsung dengan ternak dan hewan liar serta menghindari kontak dekat dengan siapa pun yang menunjukkan gejala penyakit pernapasan seperti batuk dan bersin (Kemenkes RI, 2020)

Pengetahuan yang baik tentang covid 19 menjadi faktor yang berkontribusi dalam melakukan pencegahan penyakit. Penelitian oleh Suharto dan Suminar (2017) menunjukan bahwa pengetahuan perawat memiliki hubungan dengan tindakan pencegahan infeksi di Ruang ICU $(\rho=0,024)$. Penelitian oleh Giao et al.(2020) terhadap 327 tenaga kesehatan di sebuah rumah sakit di Vietnam tentang pengetahuan dan sikap tenaga kesehatan dalam menghadapi covid 19, hasil penelitian menunjukkan bahwa sebagian besar tenaga kesehatan memiliki pengetahuan yang baik dan sikap yang positif tentang penyakit covid 19, dan sumber informasi terbanyak mereka dapatkan dari media sosial dan yang kedua dari televisi.

Mahasiwa dengan jenjang pendidikan keperawatan memiliki resiko untuk tertular Covid 19, karena mahasiswa keperawatan selain mengikuti perkuliahan kelas juga harus menjalankan praktek baik di rumah sakit, puskesmas maupun masyarakat yang dapat meningkatkan resiko paparan virus corona. pengetahuan yang baik dalam melakukan pencegahan tertularnya virus sangat penting bagi 
mahasiswa keperawatan agar tidak tertular penyakit khususnya covid 19.

Penelitian oleh Sukesih, dkk (2020) menunjukan bahwa hanya sebesar 51,35\% mahasiswa kesehatan yang memiliki pengetahuan yang baik tentang penyakit Covid 19. Penelitian lain oleh Chesser, et al (2020) pada mahasiswa di Kota Midwestern Amerika Serikat, dengan hasil penelitian menunjukan bahwa pengetahuan mahasiswa tentang covid 19 tergolong sangat rendah.

Berdasarkan studi pendahuluan yang dilakukan oleh penulis terhadap enam mahasiswa Akper Manggala Husada menunjukan mahasiswa sudah pernah mendapatkan informasi tentang covid 19 melalui media online dan sosial media ada empat mahasiwa yang mengatakan kebingungannya tentang penyebaran covid 19 karena informasi yang didapat simpang siur.

Berdasarkan penelusuran literatur bagaimana pengetahuan mahasiswa khususnya di bidang keperawatan tentang penyakit covid 19 di Indonesia belum banyak dilakukan, untuk itu perlu dilakukan penelitian tentang pegetahuan mahasiswa Akper Manggala Husada tentang covid 19 dan cara pencegahannya.

\section{Tinjauan teori}

Penyakit Covid 19 adalah penyakit infeksi yang disebabkan oleh corona virus. covid19 adalah penyakit yang disebabkan oleh turunan coronavirus baru. ' $\mathrm{CO}$ ' diambil dari corona, 'VI'virus, dan ' $\mathrm{D}$ ' disease (penyakit). Sebelumnya, penyakit ini disebut '2019 novel coronavirus' atau '2019-nCoV.' Virus covid-19 adalah virus baru yang terkait dengan keluarga virus yang sama dengan Severe Acute Respiratory Syndrome (SARS) dan beberapa jenis virus flu biasa.

Penyebab covid 19 adalah Novel Coronavirus 2019 (2019-nCoV). Coronavirus merupakan virus RNA strain tunggal positif, berkapsul dan tidak bersegmen. Coronavirus tergolong ordo Nidovirales, keluarga Coronaviridae. Coronaviridae dibagi dua sub keluarga dibedakan berdasarkan serotipe dan karakteristik genom. Terdapat empat genus yaitu alpha coronavirus, betacoronavirus, deltacoronavirus dan gamma coronavirus

Pencegahan yang dapat dilakukan untuk mencegah penularan covid 19 yaitu: 1) Pola hidup sehat (meningkatkan sistem imun tubuh) Personal higienitas yang baik 2) Etika batuk dan bersin 3) Cuci tangan, jangan menyentuh mata, hidung atau 
mulut dengan tangan kotor 4) Ventilasi ruangan yang baik, jaga tetap bersih 5) Hindari kontak dekat dengan orang dengan gejala sistem respirasi, 6) Hindari tempat ramai, jika perlu, gunakan masker, 7) Hindari kontak dengan hewan liar, unggas dan ternak 8) Makanan yang aman, dan dimasak dengan matang, 9) Hindari makan makanan yang mentah, 10) Perhatikan tanda dan gejala infeksi saluran napas (Burhan, et al 2020)

Pengetahuan adalah merupakan hasil dari "tahu", dan ini terjadi setelah orang melakukan pengindraan terhadap suatu objek tertentu. Pengindraan terjadi melalui pancaindra, yakni: penglihatan, pendengaran, penciuman, rasa, dan raba. Sebagian besar pengetahuan manusia diperoleh melalui mata dan telinga. (Notoatmodjo, 2005). Menurut Notoamojo (2012), pengukuran pengetahuan dapat dilakukan dengan memberikan seperangkat alat tes/kuesioner tentang obyek pengetahuan yang akan diukur, selanjutnya dilakukan penilaian dimana setiap jawaban benar masing-masing pertanyaan diberi nilai 1 dan jika salah diberi nilai 0 .

Pengetahuan tentang penyakit Covid 19 dapat diukur menggunakan kuesioner. Giao, et al (2020) melakukan penelitian tentang pengetahuan dan sikap tenaga kesehatan dalam menghadapi covid 19 dengan menggunakan kuesioner terdiri dari
10 item pertanyaan terkait penyakit covid 19 dan cara pencegahannya menggunakan skala guttman untuk setiap item pertanyaan dengan nilai 0 jika jawaban salah dan nilai 1 untuk jawaban yang benar dengan cut of point 7, jika nilai lebih dari 7 maka dikatakan responden memiliki pengetahuan yang baik, dan jika skore kurang dari 7 maka pengetahuan responden kurang.

\section{Metodologi}

Penelitian ini menggunakan pendekatan cross sectional yang bertujuan mengetahui pengetahuan mahasiswa Akademi Keperawatan Hermina Manggala Husada tentang covid 19 dan cara pencegahannya. Penelitian dilakukan pada 110 mahasiswa Akper Hermina Manggala Husada. Pengambilan data dilaksanakan selama bulan Agustus 2020. Instrumen yang digunakan untuk mengukur tingkat pengetahuan adalah menggunakan kuesioner yang di kembangkan sendiri oleh peneliti, dengan 20 item pertanyaan menggunakan skala guttman dengan skore 1 untuk jawaban yang benar dan skor 0 untuk jawaban yang salah. Item pertanyaan adalah pengertian covid 19 (no 1), pertanyaan tentang penyebab (2), pertanyaan tentang tanda gejala (3 dan 6), pertanyaan tentang cara penularan (4 dan 5,15), komplikasi penyakit covid $19(13,14)$ 
dan pertanyaan tentang cara pencegahan covid $19(7,8,9,10,11,16,17,18,19,20)$.

Uji validitas kuesioner dilakukan dengan uji korelasi pearson product moment sedangkan uji reliabilitasnya menggunakan Cronbach Alpha. Hasil uji validitas menggunakan pearson product moment pada kuesioner pengetahuan tentang Covid 19 didapatkan nilai validitas 0,524 - 0,734. Uji reliabilitas instrumen dilakukan dengan menggunakan Cronbach Alpha dengan reliabilitas 0,751 sehingga kuesioner dikatakan reliaabel.

Analisis data yang dilakukan menggunakan tendensi sentral. Gambaran pengetahuan mahasiswa akper diukur menggunakan skala guttman nilai 0 jika jawaban salah dan nilai 1 untuk jawaban yang benar dengan cut of point 17 , jika nilai lebih dari 17 maka dikatakan responden memiliki pengetahuan yang baik, dan jika skore kurang dari 17 maka pengetahuan responden dikatakan kurang.

\section{Hasil}

\section{Karakteristik Responden}

Diketahui bahwa mayoritas mahasiswa Akper Hermina Manggala Husada adalah berusia antara 18 samapi 21 tahun yaitu sebanyak 102 orang $(92,7 \%)$, sebagian besar responden berjenis kelamin perempuan yaitu 104 orang $(94,6 \%)$, dan sebagian besar pendapatan orang tua responden tergolong rendah yaitu sebanyak 83 orang $(75,5 \%)$.

Karakteristik responden dapat dilihat pada tabel 1 .

\section{Table 1. Karakteristik Responden (n:110)}

\begin{tabular}{lcc}
\hline \multicolumn{1}{c}{ Karakteristik } & Frek & $\mathbf{( \% )}$ \\
\hline Usia & & \\
$<18$ tahun & 0 & 0 \\
18-21 tahun & 102 & 92,7 \\
$>21$ tahun & 8 & 7,3 \\
\cline { 2 - 3 } & & \\
Jenis kelamin & & \\
Laki-laki & 6 & 5,5 \\
Perempuan & 104 & 94,5 \\
\hline Pendapatan orang tua & & \\
$<5$ juta & 83 & 75,5 \\
5-10 juta & 24 & 21,8 \\
$>10$ juta & 3 & 2,7 \\
\hline Total & $\mathbf{1 1 0}$ & $\mathbf{1 0 0 \%}$ \\
\hline
\end{tabular}

\section{Sumber informasi tentang covid 19 dan cara pencegahannya}

Sumber informasi tentang covid 19 dan cara pencegahannya dapat dilihat pada tabel 2.

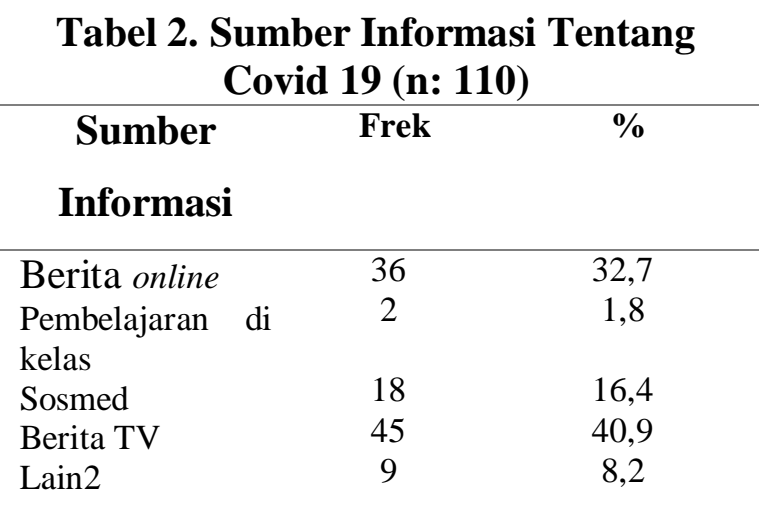

Tabel 2. Menunjukkan bahwa sebagian besar responden mendapatkan informasi tentang covid 19 paling banyak adalah 
dari media televisi yaitu sebanyak 45 orang $(40,9 \%)$.

\section{Pengetahuan Tentang Covid 19 dan Cara Pencegahannya}

Gambaran pengetahuan tentang Covid 19 dan cara Pencegahannya dapat dijelaskan pada tabel 3 .

\begin{tabular}{ccc}
\multicolumn{3}{c}{$\begin{array}{c}\text { Tabel 3. Pengetahuan Covid } 19 \text { dan } \\
\text { cara pencegahannya }\end{array}$} \\
\begin{tabular}{ccc}
$(\mathbf{n}=\mathbf{1 1 0})$ \\
Pengetahuan & Jumlah & Presentasi \\
\hline Baik & 62 & 56,4 \\
\hline Kurang & 48 & 43,6 \\
\hline
\end{tabular}
\end{tabular}

Tabel 3 menunjukan bahwa mayoritas responden memiliki pengetahuan yang baik tentang covid 19 yaitu sebanyak 82 orang (56,4\%), namun masih ada $43,6 \%$ mahasiswa yang belum memiliki pengetahuan yang baik tentang penyakit covid 19 dan cara pencehannya

\section{Pembahasan}

Hasil penelitian menunjukan bahwa mahasiwa Akper Hermina Manggala Husada memiliki pengetahuan yang baik tentang penyakit covid 19 dan cara pencegahannya. Penelitian ini sejalan dengan penelitian oleh Sukesih, dkk (2020) menunjukan bahwa sebagian besar $(51,35 \%)$ mahasiswa kesehatan yang memiliki pengetahuan yang baik tentang penyakit Covid 19, namun masih ada 49,65\% mahasiswa yang belum memiliki pengetahuan yang baik tentang penyakit corona dan cara pencegahannya.

Penelitian lain yang mendukung hasil penelitian ini adalah penelitian oleh Olaiman, et al (2020) pada mahasiswa di Jordania dengan hasil penelitian menunjukkan bahwa sebagian besar mahasiswa (56.5\%) memiliki pengetahuan yang tinggi tentang Covid 19. Penelitian lain yang mendukung hasil penelitian ini adalah penelitian oleh Mojally dan AlHindi, (2020) terhadap mahasiswa kesehatan di Mekah Saudi Arabia dengan hasil penelitian menunjukkan bahwa $>90$ mahasiswa memiliki pengetahuan yang baik tentang covid 19 .

Penelitian ini bertolak belakang dengan hasil penelitian oleh Chesser, et al (2020) pada mahasiswa di Kota Midwestern Amerika Serikat, dengan hasil penelitian menunjukan bahwa pengetahuan mahasiswa tentang covid 19 tergolong sangat rendah, hanya $18 \%$ mahasiswa yang mengetahui tanda dan gejala covid 19, bahkan kurang dari $18 \%$ mahasiswa yang mengerti tentang komplikasi lanjut dari penyakit covid 19.

Berdasarkan hasil penelitian menunjukkan bahwa mahasiswa memperoleh informasi tentang covid 19 paling banyak di dapatkan dari televisi, hal ini berbeda dengan penelitian oleh Chesser, et al 
(2020) yang menyebutkan sumber informasi terbanyak yang diperoleh mahasiswa tentang covid 19 diperoleh dari internet (39\%) dan sosial media (39), dan hanya $11 \%$ yang mendapatkan informasi dari radio dan TV, Penelitian lain oleh Pandey, et al (2020) di India dengan hasil menunjukan bahwa $48.1 \%$ masyarakat medapatkan informasi tentang covid 19 dari sosial media, $26.9 \%$ dari berita dan $14.7 \%$ dari tenaga kesehatan, sedangkan $6,6 \%$ berasal dari informasi teman.

Internet adalah salah satu sumber informasi mahasiswa yang paling mudah untuk diakses, sesuai dengan laporan lembaga survei Gallup (2012) bahwa satu dari lima orang di Indonesia (20.6\%) menggunakan internet dalam kehidupan mereka, dan dewasa ini, sebagian besar (51\%) penduduk muda Indonesia yang berusia antara 15-24 tahun menggunakan internet dalam aktivitas mereka.

Berdasarkan hasil penelitian bahwa hanya terdapat $2 \%$ mahasiswa yang memyebutkan bahwa sumber informasi covid 19 berasal dari pembelajaran, dan juga didukung oleh penelitian lain, maka penting untuk menjadikan covid 19 sebagai bahan ajar di kelas agar seluruh mahasiswa memiliki pengetahuan yang baik tentang covid 19 sehingga mahasiswa dapat melakukan pencegahan penyakit covid 19.

\section{Kesimpulan}

Mayoritas mahasiswa Akper Hermina Manggala Husada memiliki pengetahuan yang baik tentang covid 19 yaitu sebanyak 82 orang $(56,4 \%)$, namun masih ada 43, 6\% mahasiswa yang belum memiliki pengetahuan yang baik tentang penyakit covid 19 dan cara pencegahannya. Informasi tentang covid 19 dari televisi sebanyak 40,9\%, dan berita online $32,7 \%$, sosial media $18 \%$.

\section{Saran}

Hasil penelitian ini dapat dijadikan masukan bagi pengelola pendidikan untuk melakukan sosialisasi tentang covid 19 di kelas agar seluruh mahasiswa memiliki pengetahuan yang baik sehingga dapat melakukan pencegahan penyakit covid 19.

\section{Ucapan Terimakasih}

Terimakasih peneliti ucapkan kepada Ketua Yayasan Bhakti Husada Jaya, Direktur Akper Hermina Manggala Husada yang telah memberikan dukungan dalam pelaksanaan penelitian ini. 


\section{Referensi}

Burhan, et all (2020). Pneumonia covid19 diagnosis \& penatalaksanaan di indonesia. diperoleh dari https://www.persi.or.id/images/202 0/data/buku_pneumonia_covid19.p $\underline{\mathrm{df}}$

Chesser, A., Drassen, A Ham., and Woods, N.K.(2020). Assessment of COVID-19 Knowledge Among University Students: Implications for Future Risk Communication Strategies. Health Education \& Behavior: 47(4)

Dharma, K K. (2011). Metodologi penelitian keperawatan: panduan melaksanakan dan menerapkan hasil penelitian. Jakarta: trans Info Media

Dahlan, S.(2016). Besar sampel dalam penelitian kedokteran dan kesehatan.Jakarta: Epidemiologi Indonesi

Giao, H.,et al.(2020). Knowledge and attitude toward COVID-19 among healthcare workers at District 2 Hospital, Ho Chi Minh City. Asian Pacific Journal of Tropical Medicine $\cdot 2020: 13$

Gallup. (2012). Media Use in Indonesia 2012. Broadcasting Board of Governor [PDF document]. Retrieved from http://www. bbg.gov/wpcontent/media/2012/10 /gallupindonesia-brief.pdf

Huynh, G., Nguyen, T., Tran, V., Vo, K., Vo, V., \& Pham, L. (2020).

Knowledge and attitude toward COVID-19 among healthcare workers at District 2 Hospital, Ho Chi Minh City. Asian Pacific Journal of Tropical Medicine, 13(6), 260265. https://doi.org/10.4103/19957645.280396
Kemenkes RI. (2020). Infeksi Emerghing. Diperoleh pada tanggal 219 April 2020 dari https://infeksiemerging.kemkes.go. id/.

Kemenkes RI. (2020). Pedoman pencegahan dan pengendalian infeksi corona virus desease (Cavid 19). Diperoleh dari covid19.kemkes.go.id/download/R EV-04_Pedoman_P2_COVID-1

Mia. K. (2013). Hubungan antara pengetahuan tentang mata kuliah mikrobiologi dengan sikap ilmiah terhadap kesehatan. Jurnal Pengajaran MIPA: Volume 18(1)

Mojally, M dan Al-hindi, Y. (2020). Knowledge and attitudes towards the novel coronavirus (Covid-19) among health care college students in Makkah, Saudi Arabia. Medical Sciene: 24(105)

Notoatmodjo, S. (2005). Metodologi Penelitian Kesehatan. Jakarta : Rineka Cipta.

Notoamojo. 2012. Metodologi Penelitian Kesehatan. Jakarta: Rineka Cipta

Olaiman, A et al (2020). Knowledge and information sources about COVID student in jordan : a Crosssectional Study. Fonties in public health: 8(254)

Pandey, S., et al (2020). Corona virus (COVID-19) awarness assessment -a survey study among the indian population. J Clin Med Res: 2(4)

Sukesih, dkk.(2020). Pengetahuan dan sikap mahasiswa kesehatan tentang pencegahan covid-19 di Indonesia. Jurnal Ilmu Keperawatan dan Kebidanan: Vol.11(2)

Sugiyono.(2014). Metodologi penelitian kuantitaif kualitatif dan $R \& D$. Bandung: Alfabeta 
Suharto., \& Suminar, R. (2017). Hubungan pengetahuan dan sikap perawat dalam melakukan pencegahan infeksi di ruang ICU rumah sakit. Jurnal riset hesti medan: vol 1(1)

Unicef., WHO., dan IFRC. (2020). Pesan dan Kegiatan Utama Pencegahan dan Pengendalian COVID-19 di Sekolah. Diperoleh pada tanggal 19 April 2020 dari https://www.who.int/docs/defaultsource/searo/indonesia/covid19/pe san-dan-kegiatan-utamapencegahan-dan-pengendaliancovid-19-di-sekolah---indonesian-march2020.pdf?sfvrsn=5cdfea17_2

World Health Organization. (2020). Clinical management of severe acute respiratory infection when novel coronavirus (2019-nCoV) infection is suspected. interim guidance. [Serial on The Internet]. Diunduh pada tanggal 2020. Dari https://www.who.int/publicationsdetail/clinical-managementofsevere-acute-respiratoryinfection-when-novelcoronavirus(ncov)-infection-issuspected.(Jan 28th 2020)

Wang Z, Qiang W, Ke H. A Handbook of 2019-nCoV Pneumonia Control and Prevention. Hubei Science and Technologi Press. China; 2020. 